\title{
RELIGIOUS EXISTENTIALISM AS A COUNTERMEASURE TO MORALISTIC THERAPEUTIC DEISM
}

Moralistic Therapeutic Deism (MTD) is a new spiritual trend that is increasingly changing the religious landscape of in the Euro-American cultural provenience. Though appealing to the generation of 'emerging adults' (age 18-25), MTD results in undesirable life-outcomes that prompt religious scholars, theologians, and sociologists to carefully study its roots, expressions, and possible alternatives. Using S. Kierkegaard's religious existentialism as a case study, the authors argue that religious existentialism has the potential to face the detrimental effects of MTD and to reinvigorate stagnating religious communities.

Keywords: Religious Existentialism, Tradition, Moralistic Therapeutic Deism, consequential Faith, Kierkegaard.

\section{The Roots, Characteristics, and Life-Outcomes of Moralistic Therapeutic Deism}

'Moralistic Therapeutic Deism' is a terminus technicus coined by the American sociologist, professor Christian Smith (University of Notre Dame), following his extensive nation-wide survey called: National Study of Youth \& Religion [from now on cited as NSYR]. The project was designed to improve our understanding of the religious lives of American youth from adolescence into what Smith (among others) came to call "emerging adulthood" [1], using telephone survey and in-depth interview methods in several consecutive waves (2003-2015) [2]. Since the beginning of the NSYR, more than three thousand (precisely: 3,290) 13-17 year-old teenagers have been questioned through a telephone survey [3], and as these individuals aged, ca. $80 \%$ of them $(2,458)$ were questioned again as 18-23 year-olds [1, p. 3]. In Smith' own words, the survey was "a national, random-digit-dial telephone survey of U.S. households containing at least one teenager age 13-17, surveying one household parent for about 30 minutes and one randomly selected household teen for about 50 minutes'; this was followed later in 2003 by 267 'in-depth, face-to-face interviews with a subsample of the telephone survey respondents in 45 states" [1, p. 6]. Other rounds of interviews were conducted in 2007 and 2008, then in 2010, and 2014-15. The uniqueness of the survey, in addition to its methodological cogency, rests primarily in its longevity that provides researchers the invaluable opportunity to make comparisons between different stages of young adulthood, "studying how socialization, culture, practices, and individual choices interact in shaping religious faith of this age group" [4, p. 117]. Summarizing the findings of his research team, Smith claims that "the de facto dominant religion among contemporary teenagers in the United States is what we might call 'Moralistic Therapeutic Deism'” [5, p. 46], the creed of which might be summarized in the following way: "(1) A God exists who created and orders the world and watches over human life on earth; (2) God wants people to be good, nice, and fair to each other, as taught in the Bible and by most world religions; (3) the central goal of life is to be happy and to feel good about oneself; (4) God does not need to be particularly involved in one's life except when God is needed to resolve a problem; (5) good people go to heaven when they die" [5, pp. 46-47].

Even though no teenagers will use the term "moralistic therapeutic deism” (from now cited as 'MTD'), their attitudes, life choices, as well as life outcomes seem to be profoundly influenced by it. [MTD] is about (1) adopting a moralistic approach to life, believing that central to living a happy life is being a good, moral person; (2) it is also about providing certain therapeutic benefits to its adherents; (3) and finally, it is about a belief in a God, who created the world, and the laws in it, but keeps away at a safe distance. God is "not one who is particularly personally involved in our affairs - especially affairs in which we would prefer not to have God involved. Most of the time, the God of this faith keeps a safe distance" [5, p. 49].

\footnotetext{
* ${ }^{1}$ Katarina Valcova, ${ }^{2}$ Martina Pavlikova, ${ }^{3}$ Marie Roubalova

${ }^{1}$ Department of Religious Studies, Faculty of Humanities, University of Zilina, Slovakia

${ }^{2}$ Department of General and Applied Ethics, Faculty of Arts, Constantine the Philosopher University, Nitra, Slovakia

${ }^{3}$ Hussite Theological Faculty, Charles University in Prague, Czech Republic

E-mail: katarina.valcova@fhv.uniza.sk
} 
The growth to maturity of those affected by the MTD is inhibited by their overall vision of life. The type of religious faith they embrace is closely connected to the kind of social, cultural and economic environments they grow up in. Extension of formal schooling, increase in average age of entering into marriage, high demand on flexibility and mobility in the globalized job market, and the extension of parental support well into the young adults' twenties - these factors contribute to a delay in 'settling down' and to the presence of significant uncertainty in the lives of emerging adults. Furthermore, emerging adults cyclically face the process of internal investigation, creating overwhelming angst in the eyes of Mike Hayes, a University of Buffalo Catholic campus minister [6, p. 141]. Such a self-orientation often withdraws concern for others and engages individuals in a race where personal fulfillment is the ultimate goal. As emerging adults attempt to maintain their choices, and believe that they do not stand in a position to judge others, religious devotion is often something that is of no, or very low priority [1, p. 48].

Embracing a "nice guy" image of a 'god' who is called upon only as needed, and who definitely makes no real demands on the daily lives of young adults, may, at first, seem like a desirable spiritual approach to religion. This spiritual outlook may be celebrated for his therapeutic benefits in terms of making people feel good about themselves and secure vis-à-vis numerous life challenges. Yet, despite its 'niceness' and therapeutic appeal, the MTD lacks genuine transformative power and, in crucial moments when difficult decisions are to be made, it fails to provide adequate guidance and motivation to its proponents. The consequences, or the so called 'life outcomes' of this attitude are less than desirable for many of the young people studied in the survey. As Smith insightfully summarizes at the end of his Lost in Transition (2011):

"In the popular imagination, these early adult years are filled with youthful fun and freedom enjoyed in the prime of life. For some, this image is true. The actual reality for many, however, is instead one of personal struggle, confusion, anxiety, hurt, frustration, and grief... the long transition from the teenage years to full adulthood in America has a dark side that is not often talked about or portrayed by mainstream media. Some cultural activists and even academic scholars seem eager to celebrate and promote what we consider to be troubling aspects of emerging adult life. We are far less sanguine" [7, pp. 226-227].

By asserting that everything is relative to the situation, emerging adults initiate no standard to fulfill. Such lenience in society devalues all entities and redistributes value to one's personal and subjective intuition. Unwittingly embracing a social constructionist outlook on reality, most emerging adults "presuppose that most things about the sociocultural world are not fixed or given facts of nature but rather human constructions invented through shared social definitions and practices that are historically contingent, changeable, and particular" [1, p. 50]. In addition to this, in their quest to achieve sociality (social inclusion), emerging adults are consuming large amounts of intoxicating substances, and are minimizing their involvement in the political as well as civic world [4, pp. 118-119]. They do not seem to have, or know how to operate, the intellectual instruments needed for an engaged discussion, since they live a world where "claims are not staked, rational arguments are not developed, differences are not engaged, ... and universals are not recognized. Rather, differences in viewpoints and ways of life are mostly acknowledged, respected, and then set aside as incommensurate and off limits for evaluation" [1, p. 51]. In his book Lost in Transition (third in the series of research monographs on the subject), Smith depicts concrete detrimental effects of MTD in the lives of emerging adults. In their attempt to improve their social status and prestige, the emerging adults are instead confronted by the negative implications that stem from regular intoxication. With social matters controlling the orientation of countless young adults, civic involvement has subsequently deteriorated to a ghostly level, which limits the possibilities for communal gains [7, p. 142]. Drunkenness and a lack of participation beyond social entities unquestionably harm the individual in question, but it also endangers innocent bystanders as well as the surrounding community [8].

\section{The Responsibility and Potential of Institutional Religion}

The MTD approach to religious belief is particularly evident among mainline Protestant and Catholic youth, though it can also be found among black and conservative Protestants, Jewish teens, and other religious teenagers in the United States and in Europe. Church representatives, theologians, and religious sociologists are noticing major shifts in institutionalized Christianity: "either Christianity is at least degenerating into a pathetic version of itself or, more significantly, Christianity is actively being colonized and displaced by a quite different religious faith" [5, p. 57]. Traditional, creedal faith and the corresponding piety of historic Christianity appears to be waning, while the old, ecclesiastical and social structures are outwardly still in place. Or, as Horton points out, "we are living out our creed, but that creed is closer to the American Dream than it is to the Christian faith" [9, p. 21]. MTD seems to by "colonizing many historical religious traditions and, almost without anyone noticing, converting believers in the old faiths to its alternative religious vision of divinely underwritten personal happiness and interpersonal niceness" [5, p. 56]. This is an interesting phenomenon because both in Europe and in the United States, most people who identify themselves as Christians are "actually only tenuously connected to the actual historical Christian tradition", yet in their religious outlook they have, according to Smith:

"Substantially morphed into Christianity's misbegotten step-cousin, Christian Moralistic Therapeutic Deism. This has 
happened in the minds and hearts of many individual believers and, it also appears, within the structures of at least some Christian organizations and institutions. The language-and therefore experience-of Trinity, holiness, sin, grace, justification, sanctification, church, Eucharist, and heaven and hell appear, among most Christian teenagers in the United States at the very least, to be being supplanted by the language of happiness, niceness, and an earned heavenly reward" [5, pp. 56-57].

This emotive spirituality with a flavor of a watershed Christianity seems to be the result of a long term neglect on the side pastors and teachers in the church. Kenda C. Dean blames Christian leaders in the established churches, accusing them of being unfaithful by preaching and teaching a religion that is 'nice', but not transformative [10]. Youth is quick to follow their example. They think about what it means to have faith exactly as their faith models have taught them to think about it. Their belief content boils down to a 'benign positive regard' for one another, for those of other faiths who hold different convictions, and for the world in general. The MTD faith - a faith that serves to sooth us, to make us feel 'nice' and comfortable about ourselves, thus exhibits the traits of yet another post-modern version of religious idolatry.

On the other hand, it is precisely the organic, communal context of historic Christian communities, in which the mission is carried on and which has the necessary tools to help the emerging adults attain spiritual maturity that produces positive life outcomes. This can clearly be seen in Layton (et al.) who discusses seven anchors of religious commitment: (a) religious traditions, rituals, and laws; (b) God; (c) faith traditions or denominations; (d) faith community members; (e) parents; (f) scriptures or sacred texts; and (g) religious leaders [11]. In contrast to previous studies that depicted religious commitment as primarily a behavioral or attitudinal construct, the findings of Layton's study present a new conceptual understanding of commitment as primarily a relational construct. Teenagers who have highly religiously involved parents, and who grow up in healthy religious communities [12], who pray regularly, read Scripture frequently, and attend worship services routinely, are likely to be consistently involved in a religious community setting, hold faith in high regard, and practice prayer frequently. By developing homiletic, pastoral and catechetical ministries on the basis of relationships, learning, and personality development, emerging adults' level of consequential faith can escalate. According to Smith, "...every most-likely path to highly religious emerging adulthood must include combinations of distinctly different kinds of causal factors, almost always including groupings of relational, personal-subjective, and devotional-practice factors" [1, p. 227] Whether we follow religious existentialists and call this type of faith "authentic faith", or whether we follow Smith's terminology and call it "consequential faith", the NSYR states that those with "authentic"/“consequential" faith are achieving at a notably higher level desirable life outcomes than those who identify themselves as "Christians" but internalize the spiritual outlook of MTD. Authentic, consequential faith produces more personal interactions with parents, a higher probability of abstaining from addictive substances and promiscuity, and a higher level of intentional involvement in the Christian community and in civic society [3, pp. 261, 274].

"Religion provides teenagers with moral directives, confirming spiritual experiences, role models, community and leadership skills, coping skills, cultural capital, social capital, greater network closure in relationships, and intercommunity links-all of which, solid social scientific reasoning indicates, can be expected to enhance their life experiences. Most of the same mechanisms apply equally well in the lives of emerging adults... Religion therefore matters and makes a significant difference in the life experiences, beliefs, and behaviors of American 18- to 23-yearolds" [1, pp. 277-278].

Smith' findings are further supported by Dollahite who conducted a valuable research about the willingness of religious adolescents to make personal sacrifices [13]. Based on the results of his research, adolescents indicated sacrifices in five major domains: (1) societal expectations; (2) popular culture; (3) comforts and pleasures; (4) time and activities; (5) and peer relations. More revealing, however, were the reasons the young people gave for their willingness to make sacrifices. Connecting to God or a higher meaning or purpose played a high importance, as well as connecting to the faith tradition or community they were coming from. Among other motivational factors were: feeling affective benefits, fulfilling expectations (of either their peers, parents, or faith community leaders), and avoiding problems.

Whether it is the question of inner motivation, or the question of identifying concrete, tangible life outcomes [14], people of all ages (but especially young adults) "make their decisions in social contexts that powerfully influence the time, direction, and impact of those choices" [7, p. 141] and these social contexts must be taken seriously and should be intentionally employed in shaping the emerging adults' lives.

\section{The Promise of Existential Faith}

This leads us back to the topic of "authentic", "consequential" faith. The constitutive characteristic that we wish to highlight in this respect is its existential nature. Neither a "cultural Christianity", nor an emotivistic MTD spirituality, nor an "exclusively humanist" (secularistic) agenda [15] will generate the kind of life outcomes that bring fulfilment and contentment to individual human subject and a general well-being to society.

A short note on why speak about "faith" at all is in order here. The authors of this study are convinced that the spiritual aspect of human life cannot be explained away by biological, psychological, or social influences, or any combination of these three. Christian theological anthropology understands human 
being as a personal, holistic unity of the above mentioned aspects, integrating them with transcendent, spiritual realities. These provide an invaluable life orientation, inner motivational force, along with a structure of meaning and purpose. While the spiritual aspect of human existential experience can be expressed through biopsychosocial media [16], it should be distinguished as a unique, separate anthropological entity that overlaps into transcendent reality. Spiritual etiology, among other things, adds valuable insight into the multifaceted socio-ethical discourse in the contemporary debate between the secularists and those who point out a world-wide resurgence of religious traditions and new forms of spirituality. Though we no longer live in an "enchanted world", as Charles Taylor points out [17, p. 26], in which faith in God and the presence of a spiritual realm permeated daily life, humans (as individuals as well as societies) must find ways to constructively integrate experiences of the transcendent into the complex fabric of what constitutes our human predicament. The challenge is that, as postmodern thinkers, we are "so influenced by the age of reason that we cannot resist the urge to rationalize Christianity"; we are affected by the "general tendency of much of modem theology to rationalize, psychologize, or historicize some basic teaching of Christianity in order to defend it. The danger is that by so defending Christianity we compromise its very essence" [18, p. 197].

Restorationist sentiments in some contexts of institutionalized religion suggest that the best (or even only possible) way forward is to look backwards and simply perpetuate old forms of liturgy and catechetical instructions. Their expectation is that memorizing the correct answers from Catechism will restore people's faith commitment and enhance their spiritual vitality. Another proposed venue is to organize "exciting" and culturally "appealing" events during which young adults can experience intense feelings of belonging, happiness, fulfilment, etc. However, not extravagant events, nor mechanistic repetition of old doctrinal formulae or rituals, but a purposeful development of disciples through divine action is the proper and only adequate tool of existential transformation [10, p. 98]. Existential (consequential) faith emerges in historic, liturgical community of faith [19]. It is characterized by the Christian creed that summarized the vision and purpose of life as a gift of God in the narrative framework of the story of creation, redemption, and fulfillment. The current interest in grand narratives and fantasy stories across world-wide audiences connects imagination, human desire for meaning, with the concreteness of one's mundane life. These artistic renderings link past and present pieces of our shattered reality with a large supporting story - a "purpose framework". Many literary works attempt to return to the supporting story (an important aspect of modernism), but place them in a postmodern fantasy framework. Much of current literature reflects the human fear of nothingness, hopelessness, despair over the past, and anxiety about an uncertain future. Historic religious communities have the potential to "connect the dots", so to speak, to link the shattered pieces within the lives of individuals and put together (socially) the seemingly random mosaic of contradictory and competing desires and fears of human subjects into a community with a shared vision, ethos, and purpose. Consequential faith as an inner, existential disposition of the human subject, arising as a result of one's participation in the embodied narrative of the Gospel, has the potential to be this kind of bond of cohesion and life motivation.

Here, however, it is important to remember that "Faith does not mean mimicking Jesus, but participating in his self-giving love - not because we have somehow chosen to be like him, but because incredibly, God has chosen to become like us" [10, p. 104]. We can only imitate Him because we are embraced by Him; we can only follow because $\mathrm{He}$ is holding us, leading us, animating us (spiritually) from within. Transcendence lays its claim on humans, which enables humans to enter the process of "metanoia" (i.e., change of mind) and, subsequently, to recalibrate their moral compass and step forward on the path of selfless life (though never perfectly!). In any case, Evans' words on this topic serve as an important reminder that " $[\mathrm{t}]$ he quest for truth, at least the truth about the most important things, cannot be divorced from the quest to become the kind of person we need to become" [20, p. 26]. Personal transformation is an inevitable side effect of consequential, existential faith.

Soren A. Kierkegaard, above other religious existential thinkers, may serve as an incisive case study of religious existentialism. Kierkegaard, in fact, is considered the 'father' of religious existentialism [21]. This controversial Danish intellectual "feared that Christendom - the alliance of church, state, and middle-class culture - had falsely given the impression that one can have genuine faith simply by adhering to the norms of the allegedly Christian society, without undergoing a true transformation of one's passional life" [22, p. 105]. He was convinced that "Christendom bred the false and spiritually lethal attitude that faith is a matter of mere conformity. This attitude generated smugness, complacency, and militated against any passionate desire to be inwardly transformed" [22, p. 105-106]. The roots of Kierkegaard's disenchantment with the established religious culture of his day go to his fundamental understanding of anthropology. Kierkegaard defines the human self "relationally by means of an existential ontology of freedom and potentiality. The human self is thus being conceived of as an 'emerging' reality which is being constituted in the vary act of relating to itself. To become a fully constituted self, however, Kierkegaard maintains that the 'self-aware' self must relate its own relatedness to the divine origin of its being. For Kierkegaard, this divine source of each self's existence is a personal God, the God of Abraham, Isaac and Jacob, the Father of Jesus (Logos incarnated)" [23, p. 99]. Existential passion is both the product and vehicle (medium) of this selfaware relatedness to Transcendence [24, p. 699]. Existential faith, thus, must be passionate, otherwise it is not authentic faith. This "passion of faith", then, "requires the internalization of communal 
convictions and values. Kierkegaard's basic complaint with the church was that it had ceased to make it clear that Christian concepts must be appropriated by individuals with personal passion and commitment. He saw his task as reintroducing the struggle and passion of personal transformation back into the lives of the individuals who constitute the community" [22, p. 106]. Kierkegaard's religious existentialism, including, above all, the "emphasis on the role that passion and inwardness of the human subject play in the acquisition of religious truth and in the living out of that truth may be considered one of Kierkegaard's most important and enduring contributions" [22, p. 106].

\section{Conclusion: Lessons for the Ministry to the 'Emerging Adults' Generation}

The Kierkegaardian type of religious existentialism points us to the essential questions of anthropology with the aim to call human individuals to authentic subjecthood. Experiencing a self-aware, authentic existence, however, is only possible relationally in a three dimensional interplay of personal being: the self's relation to itself; the self's relation to others; and the self's relation to personal Transcendence, which is constitutive to all other relations. "Man's relatedness to God is constitutive to human personhood" [25, p. 73]. It is not the MTD infected self that picks and choses relations based on whimsical preferences; it is, rather, a new existential outlook of the relational self, embraced by Transcendence (or Spirit) [26, p. 18] - defined Christologically and Trinitarilly - that should be the goal of Christian catechesis. To facilitate such catechesis, the passing down of authentic faith, emerging adults must be guided within the community, to personally acquire the Christian creed (i.e. a theocentric vision of life), purpose (i.e. inner motivation), and hope [27, p. 215] that correlates to consequential-existential faith. Engaging in religious conversations that aspire to spawn existential faith in the hearers is critical to the development of Christian identity [28], as is a robust proclamation and enactment (both liturgical and diaconal) of the constitutive religious narrative - the triune Gospel - in the context of a living, teaching, witnessing and serving faith community. Rather than predominantly speaking from behind the altar or sponsoring big events, emerging adult need to interact with individuals (who exemplify the authentic faith) in a small setting, building gradually their religious vocabulary and witnessing abilities along the way. Effective communication equates to intentional participation from both parties, and the pace is set by those being ministered to. Upon the creation of religious speaking abilities, consequentialexistential faith "transcends into a communal zone, empowering participation that previously seemed futile. Partnerships with members of the Body of Christ grant emerging adults a personal ministerial resource that serves as a guide as well as an advocate" [4, p. 133].

\section{References}

[1] SMITH, C. \& SNELL, P.: Souls in Transition: The Religious and Spiritual Lives of Emerging Adults. New York: Oxford UP, 2009. ISBN 978-0195371796. Smith described the following socio-cultural changes that formed the lives of contemporary young adults, creating a new social group - "the emerging adults": (a) the extension of formal schooling, with college as the norm; (b) increases in the average age of marriage for both men and women; (c) changes in the global economy, which demand flexibility and change, rather than the projected stability of a life-long career; (d) the extension of parental support well into one's twenties. Ibid., p. 5-6.

[2] SMITH, C. et al.: National Study of Youth \& Religion [online]. Notre Dame: University of Notre Dame, 2003-2015. Available on the Internet: http://youthandreligion.nd.edu/. [15/01/2016].

[3] The first results of the survey were published in: SMITH, C. \& DENTON, M. L.: Soul Searching: The Religious and Spiritual Lives of American Teenagers. New York: Oxford University Press, 2005. ISBN 978-0195384772.

[4] VALCOVA, K.: Religiosity of the Emerging Adults and Cultural Challenges of the Fragmented Reality of Post-Modernism: Lessons to Learn from the us Context. S. Sorys, T. Bratkowski (eds.), Wiedza, umiejetnosc, kompetencje wobec przemian XXI wieku: spoleczenstwo - tozsamosc - religia. Krakow: Drukarnia Eikon Plus, 2014, pp. 116-134. ISBN 978-83-60391-77-8.

[5] SMITH, C.: On "Moralistic Therapeutic Deism" as US Teenagers' Actual, Tacit, de facto Religious Faith. S. Collins-Mayo (ed.), Religion and youth. Aldershot: Ashgate, 2010, pp. 41-46. ISBN 9780754667681. This book further develops the interpretations published in: SMITH, C.: Is Moralistic Therapeutic Deism the New Religion of American Youth?: Implications for the Challenge of Religious Socialization and Reproduction. In J. L. Heft (ed.), Passing on the faith: Transforming traditions for the next generation of Jews, Christians, and Muslims. New York: S. M. Fordham University Press, 2006, pp. 55-74. ISBN 9780823226481.

[6] HAYES, M.: Googling God: The Religious Landscape of People in Their 20s and 30s. New York : Paulist Press, 2007. ISBN 978-0-80914487-7.

[7] SMITH, C., et al.: Lost in Transition: The Dark Side of Emerging Adulthood. New York: Oxford UP, 2011. ISBN 9780199828029. 
[8] The NSYR showed that emerging adults are consuming alcohol and drugs extensively with intoxication being the direct result. By the age of 19 , only $14 \%$ of young adults have not been drunk before, and of the $78 \%$ who do consume alcohol, $60 \%$ have indulged in binge drinking within the last two weeks [7, pp. 110-111]. High numbers of emerging adults are participating, or once did, in dangerous activities, as partiers, addicts, recovered addicts, and recovered partiers represent $55 \%$ of the entire NSYR, which clearly shows the dominant presence of intoxicating substances in emerging adult culture. Cf.: [4, p. 128].

[9] HORTON, M. S., WILKEN, T.: Christless Christianity: The Alternative Gospel of the American Church. Grand Rapids : Baker Books, 2008. ISBN 978-0-8010-1318-8.

[10] DEAN, K. C.: Almost Christian: What the Faith of Our Teenagers is Telling the American Church. New York: Oxford UP, 2010. ISBN 978-0-19-531484-7.

[11] LAYTON, E., DOLLAHITE, D. C., HARDY, S. A.: Anchors of Religious Commitment in Adolescents. J. of Adolescent Research, vol. 26, No. 3, 2011, 381-413. ISSN 0743-5584.

[12] Cabanova points out the importance of family context for a "transgenerational transfer of values" in: CABANOVA, V.: Social Attitudes and Values of Young People in the Context of Multicultural Education. Communications - Scientific Letters of the University of Zilina, No. 3, 2014, 4-8, ISSN 1335-4205. On the topic of parental involvement in the transfer of values, see also: Pala, G.: The Family in Media Ciphers. European J. of Science and Theology, vol. 11, No. 6, 2015, 45-56. ISSN 1841-0464; PETRO, M.: Clovek ako osoba - nadej pre Europu. In P. Dancak (ed.), Sapiencialny charakter antropologie Jana Pavla II. v kontexte europskej integracie, Presov: University of Presov, 2006, 96-111.

[13] DOLLAHITE, D. C., et al.: Giving Up Something Good for Something Better Sacred Sacrifices Made by Religious Youth. J. of Adolescent Research, vol. 24, No. 6, 2009, 691-725. ISSN 0743-5584.

[14] For a good study on the presuppositions and motives for toleration (as one of the most important life-outcomes), see: Jurova, J.: Ethical Aspects of Toleration from Liberal Perspective. European J. of Science and Theology, vol. 12, No. 1, 2016, 139-145. ISSN 1841-0464.

[15] Exclusive humanists, according to Taylor [13], promote human self-sufficiency and "expressive individualism" [13, p. 213] as the fulfillment of our human potential, without any reference to transcendent sources, values, or hopes.

[16] ENTWISTLE, D. N.: A Holistic Psychology of Persons: Implications for Theory and Practice. J. of Psychology and Christianity, vol. 28, No. 2, 2009, 141-149. ISSN 0733-4273.

[17] TAYLOR, C.: A Secular Age. Cambridge Massachusetts: Harvard University Press, 2007. ISBN 978-0-674-02676-6.

[18] VALCO, M.: Alternative Viewpoint: Edwards and the World Religions. McDermott, G. (ed.). Understanding Jonathan Edwards: An introduction to America's theologian. Oxford: Oxford University Press, 2009, pp. 195-200. ISBN 978-0-19-537344-8.

[19] Lutheran reformers thus emphasized the constitutive character of liturgy, culminating in the Eucharistic feast (the Lord's Supper). In the words of Martin Chemntiz: "The Lord's Supper is closely connected to a person's faith and thus also to his/her salvation or condemnation.” Valco, M.: Scripture as a source of Chemnitz' christology. Communications: Scientific Letters of the University of Zilina, vol. 9, No. 2, 2007, 5-8. ISSN 1335-4205.

[20] EVANS, S.: Why Kierkegaard Still Matters - and Matters to Me. Why Kierkegaard Matters: A Festschrift in Honor of Robert L. Perkins. Robert L. Perkins, Marc Alan Jolley \& Edmon L. Rowell (eds.), Mercer University Press, 2010.

[21] The topic of religious existentialism, its origins as well as current intellectual potential, attracts high attention today. In relation to Kierkegaard, see: Kralik, R.: Marie Mikulova Thulstrupova (1923-2013) a jeji tvorba. Filosoficky casopis, vol. 61, No. 3, $2013,439$. 442; the legacy of D. Bonhoeffer, the German Christian existentialist, strongly influenced by Kierkegaard, is discussed in: Ligus, J.: Obedience or resistance: The legacy of Bonhoeffer. European J. of Theology, vol. 24, No. 2, 2015, 173-182. ISSN 0960-2720, KONDRLA, P., KRALIK, R.: Authentic Being and Moral Conscience. European J. of Science and Theology, vol. 12, No. 4, 2016, 155-164. ISSN 1841-0464.

[22] VALCO, M., KRALIK, R., BARRETT, L.: Moral Implications of Augustine's Philosophical and Spiritual Journey in his Confessiones, Communications - Scientific Letters of the University of Zilina, vol. 17, No. 2, 2015, 103-108. ISSN 1335-4205. On this topic, see also: Kralik, R., Torok, L.: The Moment - Kierkegaard's Attack upon Christendom. European J. of Science and Theology, vol. 12, No. 3, 2016, 112-120. ISSN 1841-0464.

[23] VALCO, M.: Kierkegaard's 'Sickness unto Death' as a Resource in our Search for Personal Authenticity. European J. of Science and Theology, vol. 12, No. 1, 2016, 97-105. ISSN 1841-0464.

[24] REPAR, P.: Existential Dialectics of Choice and Scandalon (in Slovak). Filozofia, vol. 67, No. 8, 2012, 689-704. ISSN 0046-385X.

[25] KRALIK, R., TOROK, L.: Concept of Relationship God-Man in Kierkegaard's Writing 'What we learn from the lilies in the field and from birds in the Air'. European J. of Science and Theology, vol. 12, No. 2, 2016, 65-74. ISSN 1841-0464.

[26] HAJKO, D.: Sarvepalli Radhakrisnan and "Religion of Spirit” (in Slovak). Filozofia, vol. 59, No. 1, 2004, 18-19. ISSN 0046-385X. Summarizing Radhakrisnan's philosophy, Hajko points out the potential of a synthesis of mysticism and social action (social work). 


\section{COMMNICOIIONS}

[27] DANCAK, P.: Concreteness of Life as the Context of Thinking in the Philosophy of Jozef Tischner. European J. of Science and Theology, vol. 12, No. 2, 2016, 213-221. ISSN 1841-0464.

[28] KONDRLA, P.: Apophatic Theology, Philosophy of Dialogue and Communication Perspectives. European J. of Science and Theology, vol. 12, No. 1, 2016, 117-128. ISSN 1841-0464. Kondrla reminds us that "Immediacy of essential relationship with God is also at the center of interest for philosophers of dialogue. Philosophy of dialogue was based on Jewish and Christian roots, especially personalism and Cosmology." (Ibid., p. 124). 